\title{
Trust in the source of received information as a factor related to public perception of shale gas drilling
}

\author{
Sylwia Mrozowska ${ }^{1 \cdot A, B, D, E, F, G}$, Tomasz Besta ${ }^{1 \cdot A, B, C, D, E, F}$, Barbara Kijewska ${ }^{1 \cdot B, D, E, F}$, \\ Robin Goodwin ${ }^{2 \cdot D, E, F}$, Travis Crone ${ }^{3 \cdot B, E, F}$ \\ 1: Institute of Psychology, University of Gdansk, Gdansk, Poland \\ 2: Warwick University, Coventry, United Kingdom \\ 3: University of Houston-Downtown, Houston, USA
}

Three studies were carried out to examine whether trust in sources of information on technology is related to positive attitudes toward shale gas drilling. Factors we controlled for included: scientific knowledge, universalism and security as personal values, attitudes towards science, personal and group identity fusion, political views, and valence of the media information people received. We assumed hypothesis 1 , that trust in the source of the information would be a significant predictor of positive attitudes toward shale gas, above and beyond other variables we controlled for (study 1). Also, we stated hypothesis 2, that trust in the source of information on technology in question would be related to more positive attitudes toward shale gas when more positive information is provided, and to more negative perception of gas drilling when less positive information is presented. Thus, we expected an interaction effect between trust and valence of information presented to participants (studies 2 and 3). Participants completed questionnaires in Poland (studies 1 and 2) and the USA (study 3 ). They where recruited from communities in regions where shale gas industry could potentially be developed (study 2) or has been developed (study 3 ). The results showed: (a) a significant relationship between trust in negative information on shale gas and negative attitudes toward extraction; (b) a significant interaction between trust and valence of information on shale gas. That is, trust in the source of information was related to more positive attitudes toward shale gas when a positive view is provided, and to more negative attitudes when undesirable information is presented.

KEY WORDS

trust; technology perception; attitudes

CORresponding author - Tomasz Besta, Ph.D., Institute of Psychology, University of Gdansk, 4 Bażyńskiego Str., 80-952 Gdansk, Poland, e-mail: t.besta@ug.edu.pl

AUthors' CONTRIBUtION - A: Study design - B: Data collection · C: Statistical analysis · D: Data interpretation .

E: Manuscript preparation · F: Literature search · G: Funds collection

to Cite this ARTICLE - Mrozowska, S., Besta, T., Kijewska, B., Goodwin, R., \& Crone, T. (2016). Trust in the source of received information as a factor related to public perception of shale gas drilling. Current Issues in Personality Psychology, 4(4), 240-252.

RECEIVED 22.08.2016 · REVIEWED 27.09.2016 · ACCEPTED 16.11.2016 · PUBLISHED 01.12.2016 


\section{TRUST IN THE SOURCE OF RECEIVED INFORMATION AS A FACTOR RELATED TO PUBLIC PERCEPTION OF SHALE GAS DRILLING}

Climate change (Giddens, 2009; DiMentto \& Doughman, 2014; Pettenger, 2007), declining fossil fuel extraction (Speirs, McGlade, \& Raphael, 2015; Shahriar \& Erkan, 2009), increasing global demand for energy (Calder, 2012) and changing geopolitics (Amineh \& Yang, 2009) give rise to global challenges for communities around the world, as well as governments and energy markets. The exploitation of unconventional shale gas deposits, which began in the United States and reached Europe, has changed the energy perspectives of the European Union, including Poland (IEA, 2011a). The European Union has identified a chance to de-politicize the relationship with Russia in the field of gas supply (Kratochvil \& Tichý, 2013; Dag, 2013). The strategy for smart, sustainable and inclusive growth (European Commission, 2011), binding in the European Union (EU), assumes the reduction of greenhouse gas emissions, increased use of renewable energy and improving energy efficiency by 2020 . In the last decade shale gas production in the US has become cost-effective with the application of the fissure drilling technology (Jackson, Pearson, Osborn, Warner, \& Vengosh, 2011).

Fissure drilling technology, however, has prompted controversy (Boudet et al., 2014; Brasier et al., 2011), and its environmental costs and impact on local communities have been discussed (see e.g. Davis \& Robinson, 2012). Challenges related to shale gas drilling and possible challenges for communities' growth and well-being were discussed in relation to previous energy technology breakdowns and major energy accidents (e.g. Palinkas, Patterson, Russell, \& Downs, 1993; Sovacool, 2008). Research shows that attitudes toward energy technologies are shaped by, among other factors, distrust in policymakers and media reporting (Angelique \& Culley, 2014; Culley \& Angelique, 2010), as well as its perceived impact on the community. For example, based on a survey they conducted, Jacquet and Stedman (2013, see also Jacquet, 2012) confirmed that environmental attitudes, industry leasing, and employment experience could predict attitudes toward natural gas development. Perceived impact of natural gas drilling on local environment and community correlated strongly with attitudes toward natural gas (i.e. stronger than the impact on economic and personal domains). Moreover, attitudes toward gas drilling were highly polarized (more so than toward wind farms), and became more negative as development of the drilling sites progressed.

Based on previous research and considering the impact of natural gas drilling on the local environment and community, in the present studies we explored whether trust in the source of information about shale gas drilling would be a significant determinant of positive attitudes toward shale gas, above and beyond other variables known to be important in public perception of technology.

\section{PUBLIC PERCEPTION OF SHALE GAS DRILLING IN POLAND}

The discovery of shale gas deposits in the countries of Central and Eastern Europe awoke hopes of increasing energy self-sufficiency in this region (GUS, 2014). Poland, where the share of coal in electricity production in 2013 was $79 \%$, was assessed to be the country of the region with the largest deposits ( 5.3 billion $\mathrm{m}^{3}$ ). As a consequence, Poland saw a real chance for remodeling its energy market, which is highly dependent on imports of raw materials from Russia (IEA, 2011b; Economist, 2011).

The discovery of shale gas deposits in Poland prompted "enthusiastic" discussion. From a political viewpoint, the extraction of gas was treated as an element of increasing energy security, reducing $\mathrm{CO}_{2}$ emissions but also as an opportunity for economic development of the country - wage growth, creation of new jobs and financial security for future generations (Kijewska, 2014). Studies (Jaspal, Nerlich, \& Lemańczyk, 2014) show that media reporting of the fracking technology was hegemonic and positive. The dominant tone adopted by the articles in the two largest Polish newspapers ${ }^{1}$, despite their ideological differences, was mainly positive. Polish public opinion confirmed high levels of high public support. In surveys from 2011 (CBOS, 2011), three out of four respondents (73\%) were in favor of the extraction of shale gas in Poland. In 2013 the percentage of supporters remained very high $(78 \%$ support the extraction) (CBOS, 2013). Public discussion on shale gas was accompanied by a widespread belief ( $82 \%$ of responses) that the extraction of shale gas would increase Polish energy security by reducing the country's dependence on supplies of raw materials from abroad - mainly from Russia. Respondents also expressed willingness for gas production in their place of residence (59\% for gas production, see: CBOS, 2013). Indeed the NIMBY ("not in my back yard") syndrome (Boudet, 2011; Wolsink, 2000) became visible only during actual preparation for drilling. This was mainly directed against the technology of hydraulic fracturing, or "fracking" and the communication policy of mining companies $^{3}$ (Materka, 2012).

\section{TRUST AMONG OTHER FACTORS RELATED TO ATTITUDES TOWARD TECHNOLOGY}

Arguments for and against shale gas drilling are often presented in the public debate by stakeholders 
as part of discourses that minimalize the opinions highlighted by the opponents, and the debate itself is polarized (see e.g. Cotton, Rattle, \& Van Alstine, 2014; Stephenson, Doukas, \& Shaw, 2012; Wood, 2012). Based on aforementioned studies, we could assume that this mechanism of polarization of public debate and "discourse clashes" make trust in the source of information, as well as general trust in the good intentions of the stakeholders, an important factor in the formation of attitudes toward debated technologies. Previous research in the domains of communal psychology, activism studies and technology assessment revealed that (dis)trust of policymakers and media coverage plays a significant role in both attitudes toward energy technologies and in willingness to oppose these technologies (e.g. Angelique \& Culley, 2014; Culley \& Angelique, 2010; Slovic, 1993).

In our studies we wanted to examine whether trust in the source of information on shale gas will predict positive attitudes toward gas extraction. Trust in the source of information is an important factor when it comes to social influence research, feeling of justice or power relations (Cialdini \& Goldstein, 2004; van den Bos, Wilke, \& Lind, 1998). However, our research is aimed at establishing in experimental studies whether trust in the source of information would be a significant predictor of technology evaluation above and beyond other factors often associated with risk perception and technology evaluation. Based on previous literature we controlled for various psychological and political factors.

Personal values could also act as significant predictors of risk perception and technology evaluation (Goodwin, Takahashi, Sun, \& Gaines, 2012). We concentrated on security and universality values, because they are related to worries about social security and environmental concerns. As scientific knowledge and attitudes toward science are important factors in perception of risks and benefits of technology, we also controlled for these in our study (Mielby, Sandøe, \& Lassen, 2013). Political attitudes could shape support or opposition to potentially risky technologies (Boudet et al., 2014; Clarke et al., 2015), but this may vary by culture. Alongside political preferences we assessed whether strength of personal and national identity fusion (Swann et al., 2014) is related to positive evaluation of fracking. Polling in the US specific to hydraulic fracturing has shown that the Republicans/conservatives are more supportive and Democrats/Liberals more opposed. In the US overall, $41 \%$ favored the increased use of fracking to extract oil and natural gas from underground rock formations while $47 \%$ were opposed. Republican voters supported fracking far more than the Democrats (62\% to 29\%) (Pew Research Center, 2015). As yet no such political differences in support for fracking have been observed in Poland (Ma- terka, 2012), with the national security motive for shale gas extraction broadly accepted by the public (CBOS, 2013), but this has not been subject to detailed study using appropriate measures of political values. Thus, in our study we investigated, and controlled for, the role of political views as well as strong adherence to one's country, in attitudes to shale gas.

\section{OVERVIEW OF THE PRESENT STUDIES}

In this paper we present data from three studies conducted on samples of Polish adults (study 1), participants from the Pomerania region of Poland (study 2) and from Texas, USA (study 3). For studies 2 and 3 participants were recruited specifically from (a) communities from a region that has a long history of technology of fracking and where the fossil fuel industry is an integral part of the regional economy (Houston, USA), or (b) communities from a region where shale gas was discovered very recently and where there is still no industrial fracking (Pomerania, Poland).

Possible predictors towards shale gas that we controlled for included respondents' values, political views, scientific knowledge and attitudes toward science. We also measured trust in the source of the information that participants read, and we manipulated the valence of the information about shale gas given to the participants (in studies 2 and 3). We assumed hypothesis 1 (H1), that trust in the source of the information would be a significant predictor of positive attitudes toward shale gas, above and beyond other variables we controlled for (study 1). Moreover, we stated hypothesis 2 (H2), that trust in the source of information on technology in question would be related to more positive attitudes toward shale gas when positive information is provided, and to more negative perception of gas drilling when less positive information is presented. Thus, we expected an interaction effect between trust and valence of information presented to participants (studies 2 and 3).

All studies received ethical approval either from the Institute of Psychology, University of Gdansk Ethics Committee, or University of Houston-Downtown Committee for the Protection of Human Subjects. In line with the accepted procedures, all participants were informed about the goals of the study and provided informed consent. Separate written consent was not obtained as two studies were conducted via the Internet. All participants completed an anonymous online (studies 1 and 3) or paper and pencil questionnaire (study 2), either in Polish (studies 1 and 2) or in English (study 3). Participants were free to stop answering the questions and remove themselves from the study at any time without any negative consequences. 


\section{STUDY 1}

\section{METHOD}

Participants. The study was conducted via the Internet. A random sample of registered users of the research panel Ariadna participated in study 1 in exchange for additional points that could be turned into rewards. Overall, 164 individuals (86 women) with an average age of 34.54 years $(\min 18, \max 73$, $S D=13.40)$ participated in study 1 . An invitation to participate in a study was sent to registered users, and data from those people who answered the invitation and completed the questionnaire were recorded. Although the demographic profile of the participants registered in the research panel is similar to characteristics of average Internet users, the sample we employed was not a representative sample for the general population in Poland.
Procedure and materials. Questions included demographic items (age, sex, education), and measures of predictors of perceived risk related to energy technologies. Details of scales, and their reliabilities, are provided in Table 1. The first part of the questionnaire included:

Security and Universalism values. The first set of scales included questions about security and universalism values, taken from the Schwartz Portrait Values Questionnaire and based on the Theory of Cultural Values (Schwartz \& Bilsky, 1987). Participants were asked how similar they are to a person who values security (e.g. "It is very important to him/her that his/ her country be safe. This person thinks the state must be on watch against threats from within and without), or is committed to universalism values (e.g. "She/he strongly believes that people should care for nature. Looking after the environment is important to her/ him" or "She/he thinks it is important that every per-

Table 1

Descriptive statistics for measures used in studies 1, 2 and 3

\begin{tabular}{|c|c|c|c|c|c|c|c|}
\hline Variable & $\begin{array}{c}\text { Study } \\
\#\end{array}$ & $\begin{array}{l}\text { Scale items } \\
\text { (range) }\end{array}$ & Reliability & $\min$ & $\max$ & $M$ & $S D$ \\
\hline \multirow{3}{*}{ Identity fusion } & 1 & \multirow{3}{*}{$7(0-6)$} & .95 & 0.00 & 6.00 & 3.04 & 1.37 \\
\hline & 2 & & .92 & 0.00 & 5.86 & 2.69 & 1.39 \\
\hline & 3 & & .93 & 0.00 & 6.00 & 3.01 & 1.41 \\
\hline \multirow{3}{*}{ Security values } & 1 & \multirow{3}{*}{$5(1-6)$} & .79 & 2.40 & 6.00 & 4.40 & 0.81 \\
\hline & 2 & & .74 & 2.00 & 6.00 & 4.23 & 0.91 \\
\hline & 3 & & .80 & 2.60 & 6.00 & 4.72 & 0.86 \\
\hline \multirow{3}{*}{$\begin{array}{l}\text { Universalism } \\
\text { values }\end{array}$} & 1 & \multirow{3}{*}{$6(1-6)$} & .87 & 2.67 & 6.00 & 4.45 & 0.84 \\
\hline & 2 & & .80 & 1.83 & 6.00 & 4.48 & 0.94 \\
\hline & 3 & & .88 & 1.83 & 6.00 & 4.98 & 0.84 \\
\hline \multirow{3}{*}{$\begin{array}{l}\text { Political right-left } \\
\text { - economy }\end{array}$} & 1 & \multirow{3}{*}{$1(1-10)$} & \multirow{3}{*}{-} & 1.00 & 10.00 & 4.47 & 2.66 \\
\hline & 2 & & & 1.00 & 10.00 & 6.90 & 1.95 \\
\hline & 3 & & & 1.00 & 10.00 & 5.42 & 2.41 \\
\hline \multirow{3}{*}{$\begin{array}{l}\text { Political right-left } \\
\text { - values }\end{array}$} & 1 & \multirow{3}{*}{$1(1-10)$} & \multirow{3}{*}{-} & 1.00 & 10.00 & 5.13 & 2.58 \\
\hline & 2 & & & 1.00 & 10.00 & 5.28 & 2.98 \\
\hline & 3 & & & 1.00 & 10.00 & 4.73 & 2.98 \\
\hline $\begin{array}{l}\text { Attitudes toward } \\
\text { science }\end{array}$ & 1 & $4(0-6)$ & .60 & 0.75 & 6.00 & 3.42 & 1.06 \\
\hline \multirow{2}{*}{$\begin{array}{l}\text { Scientific } \\
\text { knowledge }\end{array}$} & 2 & \multirow{2}{*}{$15(0-1)$} & .59 & 0.13 & 1.00 & 0.73 & 0.16 \\
\hline & 3 & & .60 & 0.33 & 1.00 & 0.74 & 0.16 \\
\hline \multirow{3}{*}{ Trust in the source } & 1 & \multirow{3}{*}{$5(0-6)$} & .92 & 0.00 & 6.00 & 2.83 & 1.12 \\
\hline & 2 & & .90 & 0.00 & 5.50 & 2.82 & 1.18 \\
\hline & 3 & & .89 & 0.00 & 5.40 & 2.55 & 1.30 \\
\hline \multirow{2}{*}{$\begin{array}{l}\text { Positivity of the } \\
\text { information }\end{array}$} & 2 & \multirow{2}{*}{$1(0-6)$} & - & 0.00 & 6.00 & 3.31 & 2.40 \\
\hline & 3 & & - & 0.00 & 6.00 & 3.05 & 2.21 \\
\hline \multirow{3}{*}{$\begin{array}{l}\text { Attitudes toward } \\
\text { shale gas }\end{array}$} & 1 & \multirow{3}{*}{$9(0-6)$} & .92 & 0.00 & 6.00 & 3.69 & 0.95 \\
\hline & 2 & & .87 & 0.00 & 5.67 & 3.47 & 0.92 \\
\hline & 3 & & .89 & 0.22 & 6.00 & 2.80 & 1.09 \\
\hline
\end{tabular}


son in the world be treated equally. She/he believes everyone should have equal opportunities in life").

Identity fusion. To assess participants' attachment to the country, we used the five-item identity fusion scale (e.g. "My country is me", "I am one with my country"), which was designed to tap the overlap between personal identity and national identity. Higher results suggest a stronger merger of those two identities (Gómez et al., 2011; Besta, Gómez, \& Vazquez, 2014). The identity fusion measure was a good predictor of pro-group behaviors in previous studies (e.g. Besta, Szulc, \& Jaśkiewicz, 2015; Swann, Gómez, Huici, Morales, \& Hixon, 2010; see Swann \& Buhrmester, 2015 for overview). Thus we controlled for group adherence by including this measure.

Political orientations. Our third set of predictors included questions about political views. We used two items: one for assessing participants' opinion on an economic dimension (with left-wing - welfare state, and right-wing - free-market economy, as anchors) and one assessing an ideology and values dimension (with left and right anchors, based on participants' opinions on religion, reproductive rights, etc.).

Attitudes toward science. Our fourth measure assessed positive attitudes toward science with 4 items (Sturgis \& Allum, 2004). Items examined the perception that science generally makes peoples' lives easier and more enjoyable, or that we turn to science too much and abandon religion (reverse coded).

After completing those scales, participants read a short paragraph presenting a negative opinion on shale gas fracking, based on factual arguments used in media discussions on shale gas. To differentiate the source of this negative information, participants were randomly assigned to three conditions: (a) negative opinion from in-group: Poles living in the area of possible gas extraction; (b) negative opinion from out-group: a Russian gas company; or (c) participants were asked to think about critiques of shale gas drilling in the media. We included different sources of negative information about this energy source in order to tap into real-life discussion of this issue.

Trust in the source of information. Next participants answered questions from our final set of predictors - namely trust in critiques of shale gas fracking. We created a five-item measure, with high reliability (see Table 1 for details on the scale), asking if the opinion presented in the text should be trusted, and if people expressing those opinions know what they saying (e.g. "I trust the opinions presented in the text", "The authors of the arguments mentioned in the text are trustworthy", "Persons in the text should be listened to carefully, because they know what they're saying”).

Attitudes toward shale gas extraction. The dependent variable was measured by nine items related to general evaluation of shale gas as an energy source, support for government and state investment in fracking, and the perception of low risk associated with this technology. The scale was reliable (see Table 1 for details) and items included e.g. "Overall, the extraction of shale gas in Poland is a good idea", "Investments in shale gas production should be a priority for our country", or "Shale gas extraction threatens the safety of the people" (reverse coded).

\section{RESULTS AND DISCUSSION}

Preliminary analyses. We examined the role of the source of the information when it comes to attitudes toward shale gas. We conducted two one-way ANOVAs with a Bonferroni post-hoc test, with experimental groups as the independent variable and trust or attitudes toward shale gas as the depended variable. Although positive attitudes toward shale gas were weaker when negative information was presumably provided by Poles $(M=3.50)$ than by Russians $(M=3.71)$ or by the media $(M=3.86)$, these differences were not statistically significant (all $p$ values $>.10$ ).

Trust in the source of information as predictor of attitudes toward shale gas. To explore the relationship between our predictors and attitudes toward shale gas extraction, a multiple linear regression analysis was conducted. We controlled for gender (effect coded $-1=$ male, 1 = female), education (effect coded -1 = high school level or below, 1 = above high-school level) and age, and included our predictors: security and universalism values, identity fusion with country, political identification on economy and values dimensions, attitudes toward science, and trust in the arguments against fracking technology.

As Table 2 shows, when controlling for gender, level of education and age, universalistic values, economic right-wing and low trust in critiques significantly predicted positive evaluation of shale gas fracking. Additionally, personal and national identity fusion as well as positive attitudes toward science were marginally related to attitudes toward shale gas.

Discussion. In study 1 we found that universalism, but not security values, is associated with positive attitudes toward shale gas. Moreover, both rightwing identification and strong adherence to one's country predict shale gas acceptance. We confirmed hypothesis 1 , as the strongest predictor was the level of distrust towards authors of negative arguments on fracking. People who do not trust critiques presented more positive attitudes toward shale gas extraction. Thus the role of trust in the source of information was confirmed - one should not underestimate the role of trust in social life of risk evaluation.

Study 1 was conducted on a sample that included participants from one country, and only negative information about shale gas was provided. Thus in studies 2 and 3 we recruited participants from two countries, from areas where either industry based on natural fossil fuel extraction is active and has for years been 
Table 2

Multiple linear regression analysis with enter method for variables predicting attitudes toward shale gas; study 1

\begin{tabular}{lcccc}
\hline & \multicolumn{3}{c}{ Positive attitudes toward shale gas } & \multirow{2}{*}{$t$} \\
\cline { 2 - 4 } Age & $B$ & $S E$ & $\beta$ & 1.26 \\
Gender & .01 & $<.01$ & .07 & -0.76 \\
Education & -.04 & .06 & -.05 & 1.23 \\
Security values & .07 & .06 & .07 & -0.22 \\
Universalism values & -.02 & .10 & -.02 & $3.73^{* * *}$ \\
Identity fusion & .34 & .09 & .30 & $1.85^{\mathrm{t}}$ \\
Right-wing economy & .08 & .04 & .12 & $2.47^{*}$ \\
Right-wing values & .05 & .02 & .14 & 0.60 \\
Positive to science & .01 & .02 & .04 & 0.69 \\
Trust & .04 & .06 & .05 & $-9.97^{* * *}$ \\
$N$ & -.54 & .05 & -.64 & \\
Adjusted $R^{2}$ & & & 164 & .53 \\
\hline Note. ${ }^{\mathrm{N}} p \leq .10,{ }^{*} p<.05 ;{ }^{* *} p<.01 ;{ }^{* * *} p<.001 ;$ Trust - Trust in the authors of arguments, Identity fusion - fusion with country.
\end{tabular}

integrated with the local economy (Texas, USA), or recently shale gas was discovered but industrial drilling is yet to come (Pomerania region, Poland). Moreover, in comparison to study 1 , we added one more experimental condition and introduced salience of positive or negative information about shale gas. As our goal was not to conduct a survey employing a representative sample, but to explore the relationship between trust in the source of information and attitudes toward technology using experimental settings, in studies 2 and 3 we concentrated on student participants.

\section{STUDIES 2 AND 3}

\section{METHOD}

Participants. University undergraduate students from the University of Gdansk, Poland (92 women), completing their majors in various fields (e.g. chemistry, biology, humanities, social sciences, computer science), voluntarily participated in the study 2 . Overall 149 students took part in the study, with mean age of 21.85 years $(S D=1.60)$. In study 3 respondents were 111 university undergraduate students from the University of Houston-Downtown (UHD), TX, USA (83 women), completing their majors in various fields e.g. petroleum engineering, biology, humanities, social sciences, computer science). Mean age was 26.70 years $(S D=9.29)$.

As some participants omitted certain items or scales, the number of participants might vary depending on analyses conducted.
Procedure and materials. Details of the questionnaire items are provided in Table 1 . In studies 2 and 3 participants completed the same questionnaires in either Polish (study 2) or English (study 3). We used scales as described in study 1: security and universalism values, identity fusion with one's country, political views on economic and social issues, trust in the source of information, or attitudes toward shale gas was the dependent variable. Compared to study 1 , we changed two elements of our questionnaire. First, instead of questions on attitudes toward science we used a scientific knowledge questionnaire. As scientific knowledge is considered one of the important factors influencing risk perception and technology evaluation, we used a measure, which consisted of 15 items, used previously by the BBVA Foundation in its International Study on Scientific Culture (BBVA, 2012). Example questions relate to basic scientific knowledge about the size of atoms, viruses vs. bacteria distinction, etc. (e.g. To what extent do you think it is true or false: "Antibiotics destroy viruses", "Energy cannot be created or destroyed, but only changed from one form to another", "Atoms are smaller than electrons").

As a second change we introduced different experimental conditions. This time participants were randomly assigned to read either a negative or positive opinion on the extraction of shale gas, coming from either Poles or Russians in study 2 (Polish participants; as in study 1) or Republicans or Democrats in study 3 (in the US). Opinions in the studies were based on arguments that are present in public debate and in press and Internet publications. In the positive 
information conduction, the presented paragraph was generally positive about shale gas drilling (e.g. "Because of the new technologies used in the extraction and reduction of the use of other fossil fuels, shale gas extraction even improved air quality in the regions, and emissions of $\mathrm{CO}_{2}$ fell, as did those of other harmful chemicals, including ozone and nitrogen oxides. In addition, shale gas can contribute to revenue growth and significant profits for the whole economy"). In the negative information condition, threats related to shale gas were highlighted (e.g. "The shale gas extraction method also causes other problems for humans and the environment. For example, the risk of emission of hydrogen sulfide $\left(\mathrm{H}_{2} \mathrm{~S}\right)$ and sulfur dioxide $\left(\mathrm{SO}_{2}\right)$, or a problem with the increased use of water for mining slurries and industrial fluids").

After reading the paragraph, participants completed two buffer questions on the quality of the text itself, and then our measures of the two predictors: (1) perception of the positivity of the opinion (1 item: "The authors of the arguments have a positive opinion on shale gas"), and (2) how strongly participants trust the source of the information (5 items; e.g. "The authors of the arguments mentioned in the text are trustworthy"; same items as in study 1).

\section{RESULTS AND DISCUSSION}

Preliminary analyses. We examined the role of the source of the information when it comes to perception of positivity of arguments presented, and attitudes toward shale gas. We conducted a series of analyses of variance (ANOVAs) separately for studies 2 and 3. We included source of the information as the first independent variable and valence of the information as the second independent variable. To control priming of positive vs. negative perception of shale gas, and to examine the influence of independent variables on subjective perception of positivity of the presented arguments, we included positivity of opinion as a dependent variable. In study 2, among Polish participants, only the main effect of valence of the information was significant, with people reading about positive consequences of shale gas, declaring that authors have a more positive opinion about this energy technology $(F(1,143)=270.46, p<.001)$. Similarly, when attitudes toward shale gas were considered, only one main effect of valence of arguments was significant $(F(1,145)=8.28, p=.005)$. In study 3 , among participants from the U.S., control of the manipulation revealed the same effect as that in study 2 . That is, only the main effect of valence of the information was significant, with people reading about positive consequences of shale gas, declaring that authors have a more positive opinion about this energy technology $(F(1,107)=41.49, p<.001)$. Similarly, when attitudes toward shale gas were considered, only the main effect of valence of arguments approached the level of significance $(F(1,106)=3.44, p=.066)$.

Trust as predictor of attitudes toward shale gas. To explore the proposed relationship between variables, a multiple linear regression analysis was conducted. We controlled for gender (effect coded $-1=$ male, 1 = female) and age. As predictors we included: security and universalism values, identity fusion with country, political identification on economy and values dimensions, scientific knowledge, evaluation of the presented arguments (how positive these are), and trust in the information source.

Results presented in Tables 3 and 4 reveal consistency in significant predictors of the attitudes toward shale gas despite cultural differences. That is, we observed positive relationships between those attitudes and security values, valence of presented arguments, and interplay between valence of arguments and trust in their authors. To decode those interactions, and explore whether level of trust is a moderator of this link, we divided participants into three groups: (a) those with a low level of trust towards the authors of arguments (the lowest scores on the trust scale, that is participants who were classified in the first tercile of the whole sample based on trust scores); (b) a medium level of trust (second tercile), and (c) with a high level of trust (the highest scores on the trust scale, that is participants who were classified in the third tercile of the whole sample based on trust scores). We performed correlation analyses between estimations of positivity of the arguments and attitudes toward shale gas, separately for those groups. Results are presented in Figures 1 and 2 . Among University of Gdansk students (study 2), the relationship in the low trust group was $r(46)=-.03$, $p=.843$; and in the medium trust group the correlation $r(49)=.13, p=.389$. In the high trust group, the relationship between the estimation of positivity of the arguments and positive attitudes toward shale gas $(r(49)=.39, p=.006)$ was stronger than both in the low trust group $Z=2.11, p=.001$, and in the medium trust group (although this difference was not significant) with $Z=1.36, p=.087$.

Among UHD students (study 3), a similar pattern was revealed. In the high trust group, the relationship was significant, $r(34)=.71, p<.001$, and significantly higher than in the medium trust group, $r(42)=.35, p=.022$, with a value of $Z=2.20, p=.014$; and stronger than in the low trust group, where the tested relationship was virtually non-existent, $r(31)=.09, p=.607$, with a value of $Z=3.11, p<.001$. The difference between the low and medium trust groups did not reach significance; $Z=1.13, p=.129$ (Figures 3, 4, 5 and 6).

Discussion. To sum up the results, in two studies hypothesis 2 was confirmed, and the interplay between trust in the source and valence of information about shale gas was a significant predictor of atti- 
Table 3

Multiple linear regression analysis with enter method for variables predicting attitudes toward shale gas; study 2

\begin{tabular}{|c|c|c|c|c|}
\hline & \multicolumn{3}{|c|}{ Positive attitudes toward shale gas } & \multirow[t]{2}{*}{$t$} \\
\hline & $B$ & $S E$ & $\beta$ & \\
\hline Age & .03 & .04 & .05 & 0.60 \\
\hline Gender & -.12 & .08 & -.13 & -1.64 \\
\hline Security values & .18 & .09 & .18 & $2.06^{*}$ \\
\hline Universalism values & -.10 & .08 & -.10 & -1.18 \\
\hline Identity fusion & .07 & .06 & .11 & 1.27 \\
\hline Right-wing economy & .01 & .04 & .03 & 0.35 \\
\hline Right-wing values & .02 & .03 & .07 & 0.80 \\
\hline Scientific knowledge & .19 & .48 & .03 & 0.39 \\
\hline Trust & .19 & .06 & .24 & $3.09^{* *}$ \\
\hline Positivity of the information & .07 & .03 & .18 & $2.35^{*}$ \\
\hline Trust $\times$ Positivity of the information & .20 & .06 & .24 & $3.11^{* *}$ \\
\hline$N$ & & & 149 & \\
\hline Adjusted $R^{2}$ & & & .23 & \\
\hline
\end{tabular}

Table 4

Multiple linear regression analysis with enter method for variables predicting attitudes toward shale gas; study 3

\begin{tabular}{lcccc}
\hline & \multicolumn{2}{c}{ Positive attitudes toward shale gas } & \multirow{2}{*}{$t$} \\
\cline { 2 - 4 } & $B$ & $S E$ & $\beta$ & -1.47 \\
\hline Age & -.02 & .01 & -.13 & 1.49 \\
Gender & .16 & .11 & .13 & $2.21^{*}$ \\
Security values & .32 & .15 & .26 & -1.46 \\
Universalism values & -.21 & .15 & -.16 & 0.41 \\
Identity fusion & .09 & .07 & .12 & 0.81 \\
Right-wing economy & .02 & .04 & .04 & -0.24 \\
Right-wing values & .03 & .03 & .07 & 1.26 \\
Scientific knowledge & -.14 & .59 & -.02 & .10 \\
Trust & .09 & .07 & .42 & $5.11^{* * *}$ \\
Positivity of the information & .20 & .04 & .23 & $2.62^{*}$ \\
Trust $\times$ Positivity of the information & .23 & .09 & 111 & .32 \\
$N$ & & & \\
Adjusted $R^{2}$ & & &
\end{tabular}

Note. ${ }^{t} p \leq .10,{ }^{*} p<.05,{ }^{* *} p<.01,{ }^{* * *} p<.001$, Trust - Trust in the authors of arguments, Identity fusion = fusion with country.

tudes toward gas fracking. The higher the trust in the author, the stronger was the relationship between positive valence and positive evaluation of shale gas. Moreover, when controlling for other variables, security values were related to positive attitudes toward shale gas in both samples.

\section{GENERAL DISCUSSION}

Our studies demonstrated that trust in the source of the information was the strongest predictor of attitudes toward shale gas extraction. This relationship holds even when important variables related to tech- 


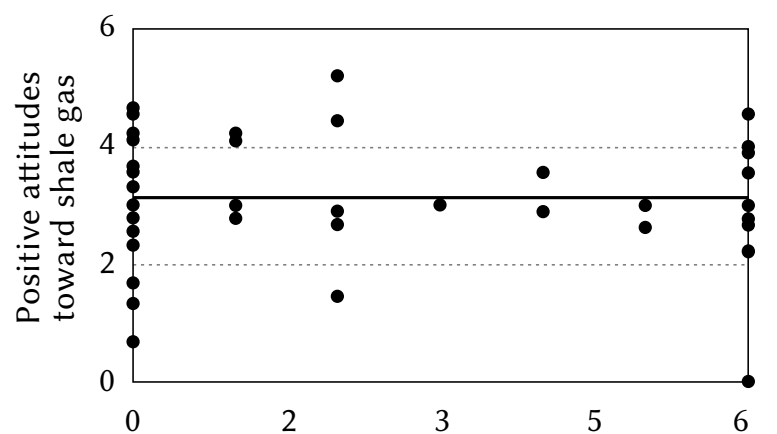

Positive valence of information about shale gas

Figure 1. Correlation analyses between perception of positivity of the arguments and attitudes toward shale gas, separately for participants with low trust in the source of the arguments in study $2 ; N=47$.

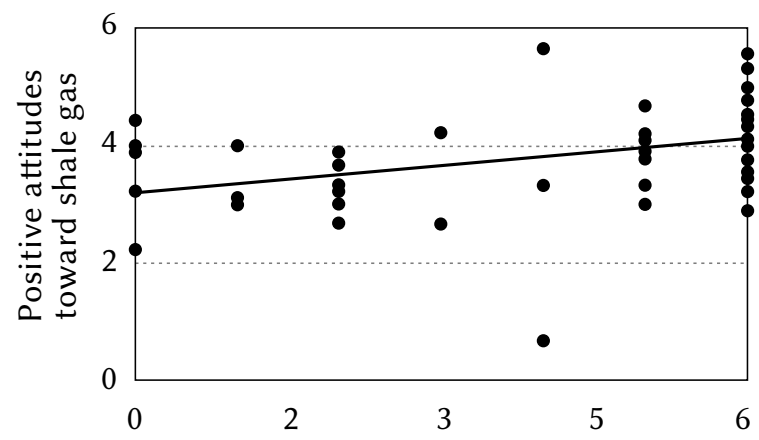

Positive valence of information about shale gas

Figure 3. Correlation analyses between perception of positivity of the arguments and attitudes toward shale gas, separately for participants with low trust in the source of the arguments in study $2 ; N=51$.

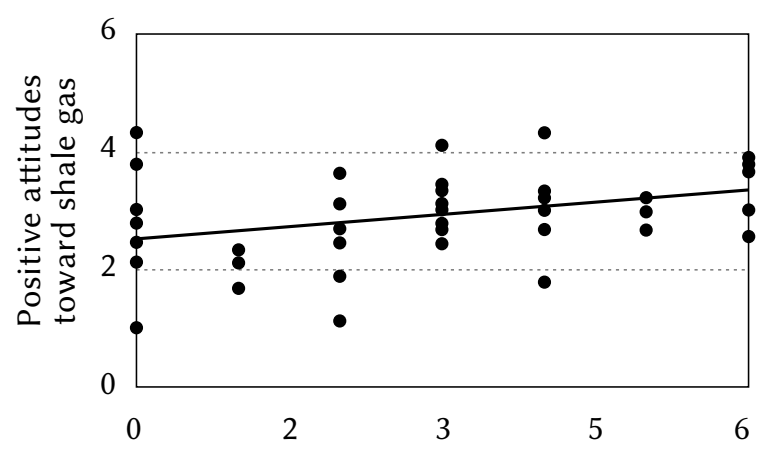

Positive valence of information about shale gas

Figure 5. Correlation analyses between perception of positivity of the arguments and attitudes toward shale gas, separately for participants with average trust in the source of the arguments in study $3 ; N=43$.

nology evaluation were accounted for (individual differences in social beliefs, values, political attitudes, attitudes toward science and scientific knowledge).

These results are important for building models of effective communication among government, citizens, and all stakeholders involved in controversial

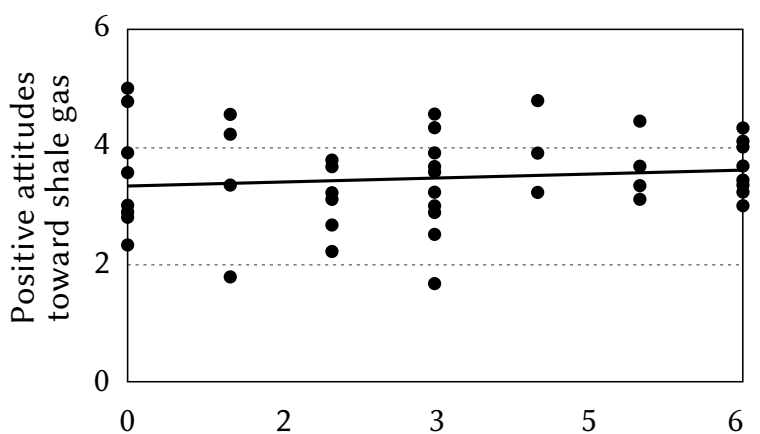

Positive valence of information about shale gas

Figure 2. Correlation analyses between perception of positivity of the arguments and attitudes toward shale gas, separately for participants with average trust in the source of the arguments in study $2 ; N=51$.

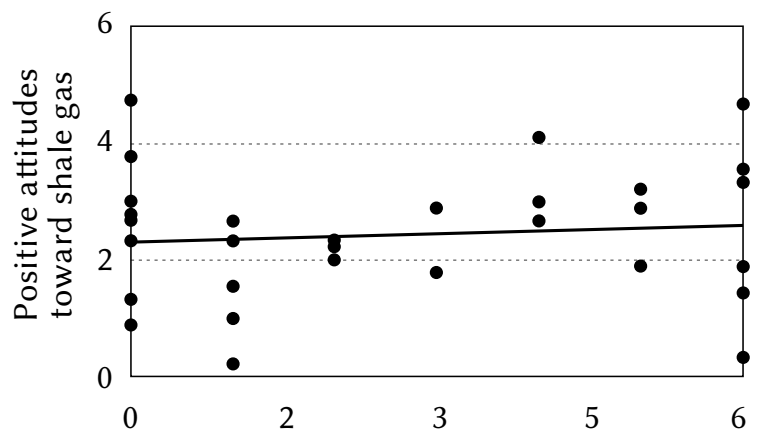

Positive valence of information about shale gas

Figure 4. Correlation analyses between perception of positivity of the arguments and attitudes toward shale gas, separately for participants with low trust in the source of the arguments in study $3 ; N=33$.

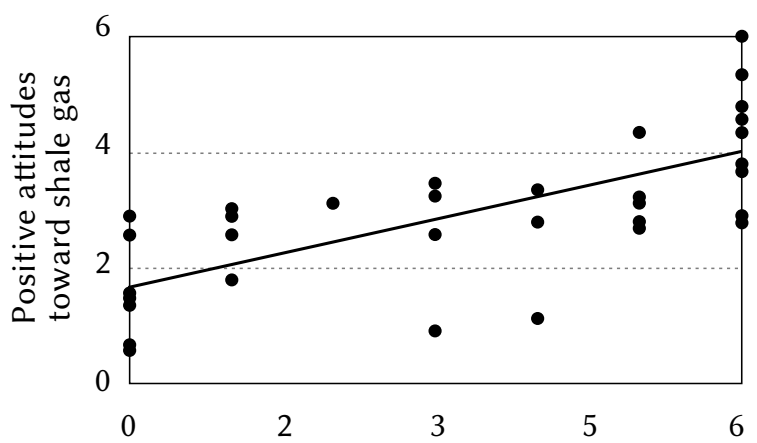

Positive valence of information about shale gas

Figure 6. Correlation analyses between perception of positivity of the arguments and attitudes toward shale gas, separately for participants with low trust in the source of the arguments in study $3 ; N=35$.

debates on investments in technologies. This may be especially true for shale gas fracturing, as protests related to this technology mount (Boudet, 2011). Although those protests are multidimensional, they are often labeled as indicating "problems with communication with society” (Łucki \& Misiak, 2012). Such 
problems have economic and political implications, and in many instances can lead to the withdrawal of proposed technological investment.

\section{SOCIAL TRUST, EXPERTS AND MASS MEDIA}

Our research highlights the role of mass media, experts' opinions and factors related to risk perception, and they link to peoples attitudes toward technologies (Łucki \& Misiak, 2012; Slovic, 1987). Mass media have an important role in framing social issues and influencing the valence of particular concerns (Deegan, Rankin, \& Tobin, 2002). Indeed, the less the public deal with a problem or have direct contact with the issue in dispute, the more public opinions depends on media coverage and the media framing of the issue (Deegan et al., 2002). Overall, there is evidence that social trust towards scientists in the field of energy and technology issues is declining (European Commission, 2007).

In Poland, where technology for shale gas extraction is new, the role of mass media in shaping public perception of this technology may be more important than in the US (where gas fracking has a longer history, and public debates are ongoing). Indeed, technological debate is relatively new in Poland (Gwiazdowicz \& Stankiewicz, 2015), compared to the more established inclusion of scientists and experts in public debates and discussions (Tran \& Daim, 2011). Notably in Poland the media campaign about shale gas was conducted mostly by the government and investors (energy companies). The lesser experience in shale gas extraction in Poland (to date there are only several test wells) could also be responsible for low social media interest (e.g. YouTube, Facebook, Twitter) in the fracking debate shown by concerned citizens. This is in contrast to the US, where social media are a source of ongoing discussions and facts (Makovsky Report, 2014).

\section{CONCLUSIONS}

\section{IMPLICATIONS FOR COMMUNITY ENGAGEMENT}

Our data show the important link between the source of information and attitudes toward energy technology. As such it is important for stakeholders to concentrate on public engagement and trust building strategies, not simple hierarchical "up-down" messages. Active inclusion in discussions has been proven to be a good way in handling community dilemmas, especially as many issues related to public perception of technology come in the form of so-called "wicked problems” (Carcasson, 2009). Empowering local community organizations could serve well as a pathway to prepare local communities for these kinds of problems. As Francescato and Aber (2015) showed in their analyses of organizational dynamics, one of the most empowering factors could be a competence in examining the various types of contributions different stakeholders make. This is especially important, as challenges related to the conflicts of values cannot easily be "solved" (e.g. because of inherent tensions between key values, such as national interest, energy independence and ecological universalism or sustainable development for future generations). Engaging people from communities directly influenced by technology investments (e.g. shale gas drilling) in such discussions and giving them the opportunity to voice their reservations can help shape social trust more than simple media coverage.

\section{LIMITATION AND FUTURE DIRECTIONS}

Our studies had several limitations. Although we conducted research in two regions where shale gas drilling is ongoing (in US) or is planned (in Poland), we did not investigate whether respondents were in any way affected (positively or negatively) by the rise of this technology. Results amongst community members where drilling took place may be a particular important. Future work could profit from inclusion of participants from other countries to further explore cultural differences, especially those affected by other technological investments. As self-interest distorts assessment of distributive justice (Białobrzeska, Bocian, Parzuchowski, Frankowska, \& Wojciszke, 2015), it would be interesting as well to examine the relationship between self-interest, personal gains from the new technology for community members, and trust in the source of the information on pros and cons related to this technology. Finally, social trust is an important factor both for societal measures of development (e.g. as a predictor of national economic growth (Bjørnskov, 2012) and for declared quality of life (Tokuda, Jimba, Yanai, Fujii, \& Inoguchi, 2008).

Trust is also important for building an informed, decision-making process that includes all stakeholders, and for willingness to cooperate with authorities (De Cremer \& Tyler, 2007). Including various measures of trust in the research on attitudes toward controversial technologies may help us build more expanded models of risk perception and technology evaluation.

\section{ENDNOTES}

1 The study analyzed the debate on fracking in two major Polish newspapers, namely Rzeczpospolita and Gazeta Wyborcza, between 1 January 2010 
and 31 December 2012. Rzeczpospolita is a centre-right and business-oriented newspaper with regular law-related editions. Gazeta Wyborcza is a centre-left newspaper and was originally the voice of the Solidarity trade union.

2 Fracking is the process whereby high-pressure water with additives is used to increase fissures in the rock layer and thereby extract shale gas embedded within the layer (Rahm, D. (2011). Regulating hydraulic fracturing in shale gas plays: The case of Texas. Energy Policy, 39, 2974-2981).

3 https://www.facebook.com/OccupyChevronPL/; http://blogpublika.com/2013/10/08/kto-gra-lupkiem-kto-gra-lupkiem-biznes-czy-spolecznosclokalna-cz-iii/.

\section{References}

Angelique, H. L., \& Culley, M. R. (2014). To Fukushima with love: Lessons on long-term antinuclear citizen participation from Three Mile Island. Journal of Community Psychology, 42, 209-227. doi: 10.1002/jcop.21605

Amineh, M., \& Yang, G. (2009). International Comparative Social Studies, Volume 21: Globalization of Energy: China and the European Union. Boston: Brill Academic Publishers.

BBVA Foundation. (2012). International study on scientific culture: Understanding of science. Bilbao: BBVA.

Besta, T., Gómez, Á., \& Vázquez, A. (2014). Readiness to deny group's wrongdoing and willingness to fight for its members: the role of the Poles' identity fusion with the country and religious group. Current Issues in Personality Psychology, 2, 49-55. doi: 10.5114/cipp.2014.43101

Besta, T., Szulc, M., \& Jaśkiewicz, M. (2015). Political extremism, group membership, and personality traits: Who accepts violence? Revista de Psicología Social: International Journal of Social Psychology, 3, 563-585. doi: 10.1080/02134748.2015.1065085

Białobrzeska, O., Bocian, K., Parzuchowski, M., Frankowska, N., \& Wojciszke, B. (2015). To nie fair (bo mi szkodzi): zaangażowanie interesu własnego zniekształca ocenę sprawiedliwości dystrybutywnej [It's not fair if I don't gain from it: Engaging self-interest distorts the assessment of distributive justice]. Psychologia Spoleczna, 10, 149-162.

Bjørnskov, C. (2012). How does social trust affect economic growth? Southern Economic Journal, 78, 1346-1368.

Boudet, H. S. (2011). From NIMBY to NIABY: regional mobilization against liquefied natural gas in the United States. Environmental Politics, 20, 786-806.

Boudet, H., Clarke, C., Bugden, D., Maibach, E., Roser-Renouf, C., \& Leiserowitz, A. (2014). "Fracking" controversy and communication: Using national survey data to understand public perceptions of hydraulic fracturing. Energy Policy, 65, 57-67.

Brasier, K. J., Filteau, M., McLaughin, D. K., Jacquet, J., Stedman, R. C., Kelsey, T. W., \& Goetz, S. (2011). Residents' perceptions of community and environmental impacts from development of natural gas in the marcellus shale: a comparison of Pennsylvania and New York cases. Journal of Rular Social Sciences, 26, 32-61.

Calder, K. E. (ed.). (2012). New Continentalism: Energy and Twenty-First-Century Eurasian Geopolitics. Yale: Yale University Press.

Carcasson, M. (2009). Beginning with the end in mind. New York, NY: Center for Advances in Public Engagement, Public Agenda.

CBOS. (2011). Wydobywać? Polacy o gazie tupkowym [To extract? Poles on shale gas]. CBOS online. Retrieved from: http://http://www.cbos.pl/SPISKOM. POL/2011/K_112_11.PDF

CBOS. (2013). Spoteczny stosunek do gazu tupkowego [Social attitudes toward shale gas]. CBOS online. Retrieved from: http://www.cbos.pl/SPISKOM. POL/2013/K_076_13.PDF

Cialdini, R. B., \& Goldstein, N. J. (2004). Social influence: Compliance and conformity. Annual Review of Psychology, 55, 591-621.

Clarke, C., Hartb, P. S., Schuldtc, J. P., Evensend, D. T. N., Boudete, H. S., Jacquetf, J. B., \& Stedmang, R. C. (2015). Public opinion on energy development: The interplay of issue framing, top-of-mind associations, and political ideology. Energy Policy, 81, 131-140.

Cotton, M., Rattle, I., \& Van Alstine, J. (2014). Shale gas policy in the United Kingdom: An argumentative discourse analysis. Energy Policy, 73, 427-438.

Culley, M. R., \& Angelique, H. (2010). Nuclear power: Renaissance or relapse? Global climate change and long-term Three Mile Island activists' narratives. American Journal of Community Psychology, 45, 231-246. doi: 10.1007/s10464-010-9299-8

Dag, H. C. (2013). The interdependence of European-Russian energy relations. Energy Policy, 59, 784-791.

Davis, J. B., \& Robinson, G. R. (2012). A geographic model to assess and limit cumulative ecological degradation from Marcellus Shale exploitation in New York, USA. Ecology and Society, 17, 25.

De Cremer, D., \& Tyler, T. R. (2007). The effects of trust in authority and procedural fairness on cooperation. Journal of Applied Psychology, 92, 639-649.

Deegan, C., Rankin, M., \& Tobin, J. (2002). An examination of the corporate social environmental disclosures of BHP from 1983-1997. A test of legitimacy theory. Accounting, Auditing \& Accountability Journal, 15, 312-343.

DiMentto, J. F., \& Doughman, P. (eds.). (2014). Climate change: What it means for us, our children, and our grandchildren ( $2^{\text {nd }}$ ed.). Cambridge, Massachusetts, London: MIT Press. 
Economist. (2011). The Future of Natural Gas. Coming Soon to a Terminal Near You. The Economist. Retrieved from: http://www.economist.com/node/ 21525381

European Commission. (2007). Eurobarometr. Energy technologies, knowledge, perception, measures. European Commission Report. Retrieved from: http://ec.europa.eu/public_opinion/archives/ebs/ ebs_262_en.pdf

European Commission. (2011). EUROPE 2020: A strategy for smart, sustainable and inclusive growth. Retrieved from: http://ec.europa.eu/eu2020/pdf/ COMPLET\%20EN\%20BARROSO $\% 20 \% 20 \% 20$ 007\%20-\%20Europe\%202020\%20-\%20EN\%20version.pdf

Francescato, D., \& Aber, M. S. (2015). Learning from Organizational theory to Build Organizational Empowerment. Journal of Community Psychology, 43, 717-738. doi: 10.1002/jcop. 21753

Giddens, A. (2009). The politics of climate change. Cambridge: Polity Press.

Gómez, A., Brooks, M. L., Buhrmester, M. D., Vázquez, A., Jetten, J., \& Swann, W. B., Jr. (2011). On the nature of identity fusion: insights into the construct and a new measure. Journal of Personality and Social Psychology, 100, 918-933. doi: 10.1037/a0022642

Goodwin, R., Takahashi, M., Sun, S., \& Gaines, S. O., Jr. (2012). Modeling psychological responses to the great East Japan earthquake and nuclear incident. PLoS One, 7, e37690. doi: 10.1371/journal. pone. 0037690

GUS. (2014). Gospodarka paliwowo-energetyczna w latach 2012-2013 [Fuel and Energy Economy in 2012-2013]. Warsaw: Główny Urząd Statystyczny [Central Statistical Office].

Gwiazdowicz, M., \& Stankiewicz, P. (eds.). (2015). Technology Assessment. Problematyka oceny technologii [Technology Assessment. Issues in technology evaluation]. Studia BAS, 3, 35-54.

IEA. (2011a). Are we entering a golden age of gas? Special Raport. World Energy Outlook.

IEA. (2011b). Energy Policies of IEA Countries 2011 Review: Poland. Retrieved from: http://www.iea. org/publications/freepublications/publication/poland2011_web.pdf

Jackson, R. B., Pearson, B. R., Osborn, S., Warner, N. R., $\&$ Vengosh, A. (2011). Research and policy recommendations for hydraulic fracturing and shale gas extraction. Center on Global Change, Duke University, Durham, NC.

Jacquet, J. B. (2012). Landowner attitudes toward natural gas and wind farm development in northern Pennsylvania. Energy Policy, 50, 677-688.

Jacquet, J. B., \& Stedman, R. C. (2013). Perceived impacts from wind farm and natural gas development in Northern Pennsylvania. Rural Sociology, 78(4), 450-472. doi: 10.1111/ruso. 12022
Jaspal, R., Nerlich, B., \& Lemańczyk, S. (2014). Fracking in the Polish press: Geopolitics and national identity. Energy Policy, 74, 253-261.

Kijewska, B. (2014). Problematyka energetyczna w ujęciu politycznym: Kwestie energetyczne w programach politycznych [The political aspect of energy: Energy issue in political party programmes]. Przeglad Naukowo-Metodyczny. Edukacja dla Bezpieczeństwa, 7, 927-939.

Kratochvíl, P., \& Tichý, L. (2013). EU and Russian discourse on energy relations. Energy Policy, 56, 391-406.

Łucki, Z., \& Misiak, W. (2012). Energetyka a spoteczeństwo. Aspekty socjologiczne [Power engineering and society. Sociological aspects]. Warszawa: Wydawnictwo Naukowe PWN.

Makovsky Report. (2014). Fracking in the Digital Landscape. Retrieved from: http://www.makovsky. com/component/content/article/47-insights/ case-studies/rich-media-case-study/667-frackingin-the-digital-landscape-report

Materka, E. (2012). Poland's quiet revolution: The unfolding of shale gas exploration and its discontents in Pomerania. Central European Journal of International and Security Studies, 6, 189-218.

Mielby, H., Sandøe, P., \& Lassen, J. (2013). The role of scientific knowledge in shaping public attitudes to GM technologies. Public Understanding of Science, 22, 155-168.

Palinkas, L. A., Patterson, J. S., Russell, J., \& Downs, M. A. (1993). Community patterns of psychiatric disorders after the Exxon Valdez oil spill. American Journal of Psychiatry, 150, 1517-1523.

Pettenger, M. E. (ed.). (2007). Social Construction of Climate Change: Power, Knowledge, Norms, Discourses. Burlington: Ashgate Publishing Group.

Pew Research Center. (2015). How Americans view the top energy and environmental issues. Retrieved from: http://www.pewresearch.org/key-data-points/ environment-energy-2/

Schwartz, S. H., \& Bilsky, W. (1987). Toward a universal psychological structure of human values. Journal of Personality and Social Psychology, 53, 550-562.

Shahriar, S., \& Erkan, T. (2009). When will fossil fuel reserves be diminished? Energy Policy, 37, 181-189.

Slovic, P. (1987). Perception of risk. Science, 236, 280-285.

Slovic, P. (1993). Perceived risk, trust, and democracy. Risk Analysis, 13, 675-682. doi: 10.1111/j.15396924.1993.tb01329.x

Speirs, J., McGlade, C., \& Raphael, R. (2015). Uncertainty in the availability of natural resources: Fossil fuels, critical metals and biomass. Energy Policy, 87, 654-664.

Stephenson, E., Doukas, A., \& Shaw, K. (2012). Greenwashing gas: Might a "transition fuel" label legitimize carbon-intensive natural gas develop- 
ment. Energy Policy, 46, 452-459. doi: 10.1016/j. enpol.2012.04.010

Sturgis, P., \& Allum, N. (2004). Science in society: Re-evaluating the deficit model of public attitudes. Public Understanding of Science, 13, 55-74.

Sovacool, B. K. (2008). The costs of failure: A preliminary assessment of major energy accidents, 1907-2007. Energy Policy, 36, 1802-1820.

Swann, W. B., Buhrmester, M. D., Gómez, M., Jettem, J., Bastian, B., Vázquez, A., ..., Zhang, A. (2014). What makes a group worth dying for? Identity fusion fosters perception of familial ties, promoting self-sacrifice. Journal of Personality and Social Psychology, 106, 912-926. doi: 10.1037/ a0036089

Swann, W. B., \& Buhrmester, M. D. (2015). Identity fusion. Current Directions in Psychological Science, 24, 52-57. doi: 10.1177/0963721414551363

Swann, W. B., Jr., Gómez, A., Huici, C., Morales, J. F., \& Hixon, J. G. (2010). Identity fusion and self-sacrifice: arousal as a catalyst of pro-group fighting, dying, and helping behavior. Journal of Personality and Social Psychology, 99, 824-841. doi: 10.1037/ a0020014

Tokuda, Y., Jimba, M., Yanai, H., Fujii, S., \& Inoguchi, T. (2008). Interpersonal trust and quality-of-life: A cross-sectional study in Japan. PloS One, 3, e3985. doi: 10.1371/journal.pone.0003985

Tran, T., \& Daim, T. U. (2011). Technology assessment. In T. Daim, N. Gerdsri, \& N. Basoglu (eds.), Technology assessment. Forecasting future adoption of emerging technologies (pp. 1-17). Berlin: Erich Schmidt Verlag.

Van den Bos, K., Wilke, H. A. M., \& Lind, E. A. (1998). When do we need procedural fairness? The role of trust in authority. Journal of Personality and social Psychology, 75, 1449-1458. doi: 10.1037/00223514.75.6.1449

Wood, J. (2012). The global anti-fracking movement: What it wants, how it operates and what next. Control Risk Group, London. Retrieved from: http:// www.marcellusprotest.org/sites/marcellusprotest.org/files/shale_gas_whitepaper.pdf

Wolsink, M. (2000). Wind power and the NIMBYmyth: institutional capacity and the limited significance of public support. Renewable Energy, 21, 49-64. 